\title{
First Quarter Screening for Aneuploidy
}

\author{
FLORINA NELA OSVAR ${ }^{1}$, ADRIAN RATIU ${ }^{2}$, FLORICA VOITA-MEKERES ${ }^{1 *}$, GABRIEL MIHAI \\ MEKERES ${ }^{1}$, FLORIN GHEORGHE VOITA ${ }^{1}$, AHMED ABU-AWWAD ${ }^{2} *$, MARIUS BEMBEA ${ }^{1}$ \\ ${ }^{1}$ University of Oradea, Faculty of Medicine and Pharmacy, 1 Universitatii Str., 410087, Oradea, Romania \\ ${ }^{2}$ Victor Babes University of Medicine and Pharmacy, 2 Eftimie Murgu Sq., 300041, Timisoara, Romania
}

\begin{abstract}
The objective of this paper is to evaluate the rate of detection of chromosomal abnormalities through the non-invasive prenatal test (NIPT) and its contribution to reducing the number of invasive tests. We conducted a prospective study on a batch of 3,000 single-pregnancy pregnancies highlighted in the first trimester. The patients were divided into two study groups, the first group, which we will call the TPNI (Non-Invasive Prenatal Test) group. First trimester screening was performed by noninvasive prenatal test at 10 weeks, and ultrasound between 11-13 +/- 6 days according to the criteria of the Fetal Medicine Foundation (FMF. London, UK). The sensitivity, specificity and accuracy of the two screening methods are almost similar, using NITP screening we obtain a rate of approximately $20 \%$ lower false-positive results, and we also perform a smaller number of invasive tests.
\end{abstract}

Keywords: aneuploidy, combined screening, non-invasive prenatal test

Until recently, fetal genetic testing for the diagnosis of aneuploidy has required invasive methods that involve a significant risk of abortion. Since 1997 it has been shown that free circulating fetal DNA in maternal blood that originates from the placenta and is rapidly eliminated after birth can be highlighted and is useful for the diagnosis of many fetal pathologies. Thus, maternal blood has become a valuable source of genetic material for prenatal diagnosis, starting in the first trimester of pregnancy. This free circulating fetal DNA is mixed with a large amount of maternal DNA and the methods used did not allow complete separation of the two DNAs in vitro.

Initially, the research focused on the detection or exclusion of fetal DNA inherited from the father and not present in maternal DNA, such as Y chromosome sequences in male faces or Rh antigen in Rh negative women. New DNA sequencing technologies allow very precise differentiation of DNA fragments, and the surplus of genetic material resulting from fetal trisomies with high accuracy can be detected.

In 1999 it was shown that in fetal pregnancies with Down Syndrome is a higher concentration of fetal DNA in maternal blood [1]. Since then, numerous methods have been described for measuring the amount of free fetal DNA circulating in maternal plasma, DNA methylation and analysis of circulating DNA and measurement of allelic ratio [24].

In 2007, an evaluation based on molecular counting by polymerization reaction in digital chain was reported, thus counting the individual DNA molecules [5-6]. The advantage of this method would be that the large number of DNA molecules counted would allow easier differentiation. The number of DNA molecules that need to be counted in the maternal plasma to detect a fetus with Down syndrome is inversely proportional to the percentage of fetal DNA. One possible explanation for the success of this technique results from the fact that the proportion of free flowing fetal DNA is actually higher than originally thought [7]. However, the fraction of fetal DNA in the sample analyzed still has a strong effect on the safety of the result [8-11].

The combined test, which uses the combined analysis between measurement of the nuchal translucency and serological markers, was the one recommended until recently as a screening test for the detection of chromosomal abnormalities, having an accuracy in detecting Down syndrome of $90 \%$, with a false positive rate of results of $3 \%$. In 2008, Lo and Quake [12-13] described the Massively Parallel Sequencing (MPS) method which allows a very good detection of Down's Syndrome in plasma.

The results of the non-invasive prenatal test are superior, with a sensitivity and specificity for detecting Down Syndrome of almost $100 \%$. Thus, the introduction of combined screening has led to a significant reduction in invasive testing and at the same time a reduction in the costs and number of abortions directly related to the procedure. [14-17]

The objective of this paper is to evaluate the detection rate of chromosomal abnormalities through the non-invasive prenatal test and its contribution to reducing the number of invasive tests.

*email: mekeres_florina@yahoo.com; ahm.abuawwad@gmail.com 


\section{Experimental part}

We conducted a prospective study on a batch of 3,000 single-pregnancy pregnancies highlighted in the first trimester. The study was carried out for a period of 3 years: 2015-2018 in the County Clinical Emergency Hospital, Oradea, Stationar 3 and the Municipal Emergency Clinical Hospital, Timisoara, in Obstetrics-Gynecology Department.

The patients who referred for pregnancy monitoring in the first trimester or were sent for screening in fetal abnormalities. Two screening methods were proposed and depending on their choice, they were divided into two study groups.

In the first batch, which we will call the Prenatal Non-Invasive Test (PNIT), the first trimester screening was performed by the non-invasive prenatal test at 10 weeks and the ultrasound between 11-13 weeks $+/-6$ days according to the criteria of Fetal Medicine Foundation (FMF. London, UK).

Lot two, which we will call the FMF Lot, performed the classic screening according to the criteria of the Fetal Medicine Foundation, they were dosed from Free Beta hCG and PAPP-A maternal blood at 10 weeks, the analyzes were performed with equipment compatible with the FMF software (Bhrams Kryptor and Delphia Express), and the ultrasound was performed at 11-13 weeks +6 weeks.

The first trimester ultrasound was performed on both batches according to FMF criteria. It followed the protocol: measurement of the cranio-caudal length (CRL) and nuchal translucency, evaluation of the presence or absence of the nasal bone, measurement of the pulsatility index (PI) of the venous duct, evaluation of the presence or absence of tricuspid epidural regurgitation and fetal evaluation.

The measurement of the nuchal translucency: it was made at the gestational age between 11-13 weeks $+/-6$ days, the embryo having a cranio-caudal length between 45 and $84 \mathrm{~mm}$. The image is enlarged so that only the head and the chest are on the screen, the average incidence Sagittarius in which to visualize the hyperecogenic line of the tip of the nose, palate, diencephalon and posteriorly the nuchal membrane and visualization of the amniotic membrane. With the fetus in the neutral position, the nuchal translucency was measured in its largest portion, and in the presence of a pericervical cord circular, two measurements were performed, cranial and distal circular, the arithmetic mean of the two measurements being performed (Fig. 1).

Nasal bone assessment: it was performed under the same conditions as for the measurement of nuchal translucency but with the transducer parallel to the direction of the nose. The presence of three distinct lines was evaluated, the nasal bone, the overlying skin, forming the so-called "equal" sign and the tip of the nose. The nasal bone was noted to be present if its echogenicity was superior or similar to that of the overlying tegument (Fig. 2).

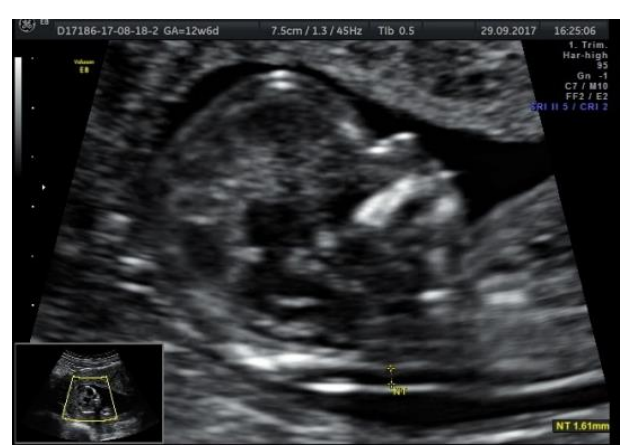

Fig. 1. Measurement of nuchal translucency

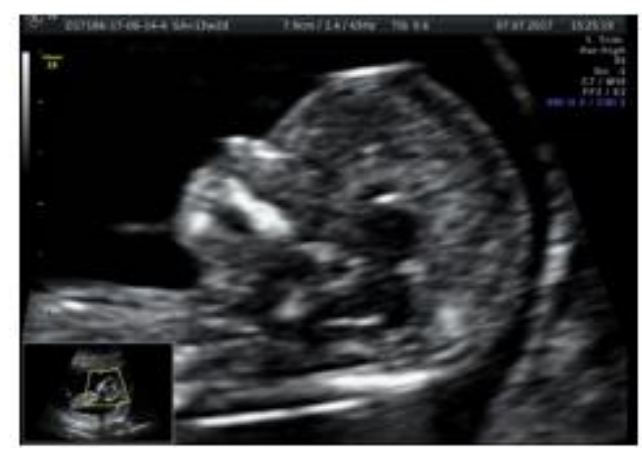

Fig. 2. Evaluation of the nasal bone

Evaluation of the Venous Duct: On a right mid-sagittal section of the fetal trunk and using the color Doppler, the umbilical vein, the venous duct and the fetal cord are highlighted. The gate of the Doppler pulsed between $0.5-1 \mathrm{~mm}$ is placed in the turbulence zone, the insulation angle being below 30 degrees, the filter at the frequency of $50-70 \mathrm{~Hz}$, speed 2-3 cm / s. The "a" wave is evaluated qualitatively, whether it is positive or negative and the pulsatility index (PI) is measured. (Fig. 3)

Tricuspid flow: Obtain a 4-chamber apical section, place the 2-3 mm pulsed Doppler gate at the tricuspid valve, with a caliper in the ventricle and one in the atrium, the insulation angle below 30 degrees, and the speed of $2-3 \mathrm{~cm} / \mathrm{s}$. Tricuspid regurgitation is diagnosed if at least half of the systole is present and with a velocity of at least $60 \mathrm{~cm} / \mathrm{s} 16$ [16] (Fig. 4). 


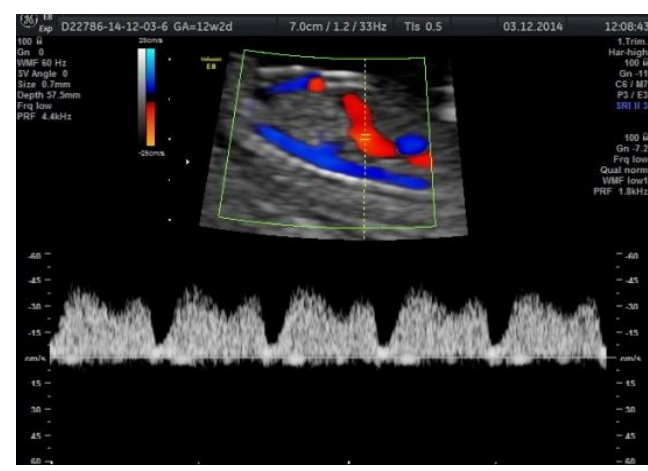

Fig. 3. Evaluation of the venous duct

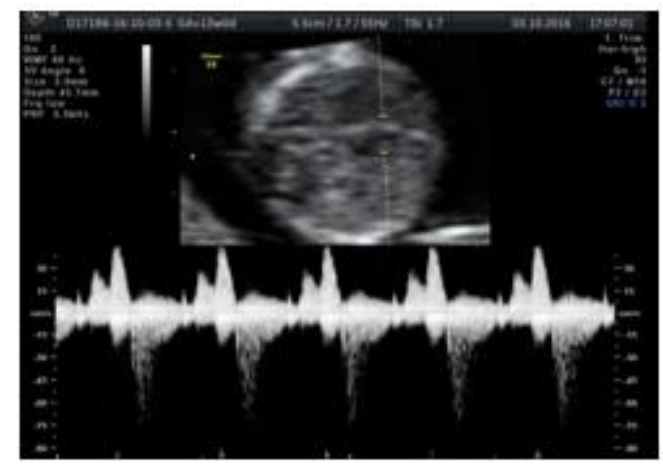

Fig. 4. Evaluation of the tricuspid valve

Evaluation of fetal morphology: all fetuses were evaluated morphologically by segmental evaluation:

Fetal head - shape, cranial ossification, intracerebral median echo completely anterior-posterior, bilateral choroid plexuses, symmetry of structures, posterior fossa.

Fetal face - bilateral orbits, face profile, nasal bone ossification.

Neck - alignment with the trunk in all spatial planes, lack of fluid accumulation such as: hygroma or jugular lymphatic sacs, nuchal translucency (TN), intracranial translucency.

Chest - the thoracic wall without defects, both lung areas present, the presence of the interface (anecogenicity / hypoechogenicity identified with the diaphragm) that separates the abdominal and thoracic cavities, without pleural effusion, tumors or atypical structures.

Fetal heart - regular heart rate, heart position on the left side, left heart axis.

Color Doppler to highlight two separate atrio-ventricular blood flows and aorto-pulmonary convergence ("V / Y sign")

Fetal abdomen - the presence of the stomach in the upper left sub-diaphragmatic quadrant, the presence of bilateral kidneys or bladder.

The abdominal wall - the normal insertion of the umbilical cord, the absence of defects.

Spine - correctly aligned vertebrae (longitudinal and transverse), intact overlying tegument.

Members - the presence of two lower members and two upper members with three segments.

Umbilical cord: number of vessels, presence of cord cysts.

The external genitals of the fetus

Both groups were followed by ultrasound markers suggestive for chromosomal abnormalities: nuchal translucency, absence of nasal bone, negative "a" wave on the venous duct and presence of tricuspid regurgitation. It was noted the existence of minor markers: single umbilical artery, as well as the existence of structural anomalies.

The PNIT group performed one of the non-invasive prenatal tests available on the market and subsequently ultrasound. In the situation of a PNIT with high risk for chromosomal abnormalities or microdeletions without ultrasonically visible structural anomalies, chorionic villus puncture (CVS) was performed for confirmation. In the case of a low-risk PNIT without ultrasound structural abnormalities, routine pregnancy monitoring was continued, and in the case of a low-risk PNIT with ultrasound visible structural abnormalities CVS or amniocentesis was performed after 16 weeks with classical and molecular karyotype, as appropriate. For all patients in this group, the risk of aneuploids according to the FMF algorithm was also calculated.

The PNIT group performed one of the non-invasive prenatal tests available on the market and subsequently ultrasound. In the situation of a PNIT with high risk for chromosomal abnormalities or microdeletions without ultrasonically visible structural abnormalities, chorionic villus puncture (CVS) was performed for confirmation. In the case of a low-risk PNIT without ultrasound structural abnormalities, routine pregnancy monitoring was continued, and in the case of a low-risk PNIT with ultrasound visible structural abnormalities CVS or amniocentesis was performed after 16 weeks with classical and molecular karyotype, as APPROPRIATE. For all patients in this group, the risk of aneuploids according to the FMF algorithm was also calculated.

Data analysis was performed using Graph Pad Prism.

\section{Results and discussions}

In the period 2015-2018, 3000 pregnancies aged 6-13 + 6 weeks were evaluated prospectively, which were addressed on their own initiative or sent for a second opinion in our service.

The ultrasound abnormalities identified were the following:

- 46 cases with structural anomalies,

- 45 cases with suggestive markers for chromosomal abnormalities and increased adjusted risk (increased TN, absent nasal bone, isolated or associated with pathological venous duct and / or tricuspid regurgitation) 
- 19 cases with minor markers (omfalocel, single umbilical artery, inverted "a" wave in isolated venous duct and isolated tricuspid regurgitation, isolated nasal bone absent).

Table 1

ULTRASOUND ABNORMALITIES AND INCREASED RISK IN THE FMF GROUP

\begin{tabular}{|c|c|c|c|c|c|}
\hline & Down & Edwards & Patau & $\begin{array}{c}\text { Anomalii } \\
\text { cromoz. sex }\end{array}$ & $\begin{array}{c}\text { Cariotip } \\
\text { normal }\end{array}$ \\
\hline $\begin{array}{c}\text { Markers present with high } \\
\text { adjusted risk 1: 100 }\end{array}$ & 20 & 7 & 3 & 5 & 10 \\
\hline
\end{tabular}

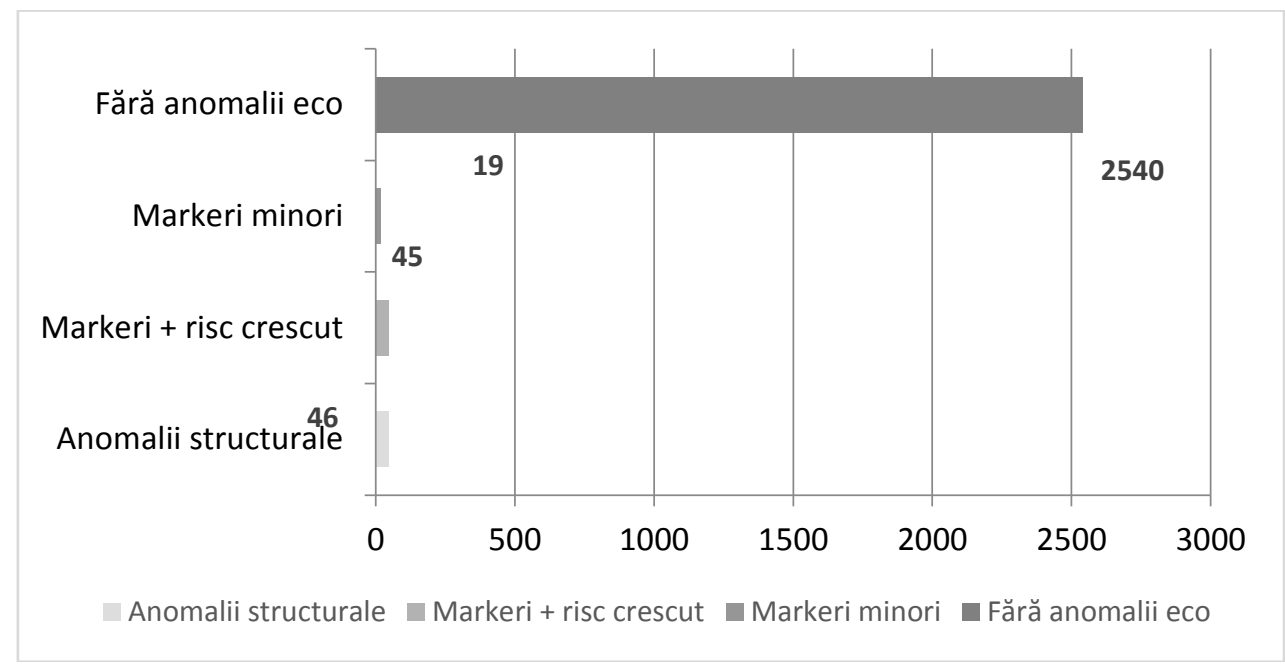

Fig. 5. FMF lot ultrasound abnormalities

Of the 69 cases that were at intermediate risk, we had 19 situations with minor ultrasound markers; 4 with single umbilical artery, 4 with absent nasal bone, 7 with tricuspid regurgitation and 4 with abnormal venous duct. 6 cases were classified at intermediate risk due to the existence of a small value of PAPP-A $\square 0.25 \mathrm{MoM}$, and the remaining 44 due to the advanced maternal age. (Table 2) Non-invasive prenatal test was performed in all patients.

Table 2

THE CASES WITH INTERMEDIATE RISK IN THE FMF GROUP

\begin{tabular}{|c|c|c|c|c|c|c|c|}
\hline & $\begin{array}{c}\text { Unique } \\
\text { umbilical } \\
\text { artery }\end{array}$ & $\begin{array}{c}\text { Nasals } \\
\text { absent }\end{array}$ & $\begin{array}{c}\text { Tricuspid } \\
\text { regurgitation }\end{array}$ & $\begin{array}{c}\text { Anormal } \\
\text { DV }\end{array}$ & $\begin{array}{c}\text { PAPP-A <0.25 } \\
\text { MoM }\end{array}$ & $\begin{array}{c}\text { Older } \\
\text { maternal } \\
\text { age }\end{array}$ \\
\hline Intermediar Risc & 4 & 4 & 7 & 4 & 6 & 44 \\
\hline
\end{tabular}

Of the cases with intermediate risk, only one case of Down syndrome was confirmed, in which no ultrasound markers were identified, only a PAPP-A of $0.12 \mathrm{MoM}$, confirmed by invasive testing. The other cases with ultrasound markers, advanced maternal age and low PAPP-A were at low risk at PNIT.[18-22]

If we analyze the cases at high risk according to the FMF algorithm, we observe that a number of 45 chorionic villi were performed, with Down Syndrome being detected in 20 cases, Edwards Syndrome in 7 cases, Patau Syndrome in 3 cases, Turner Syndrome in 3 cases and XXX in 2 cases. (Fig. 6)

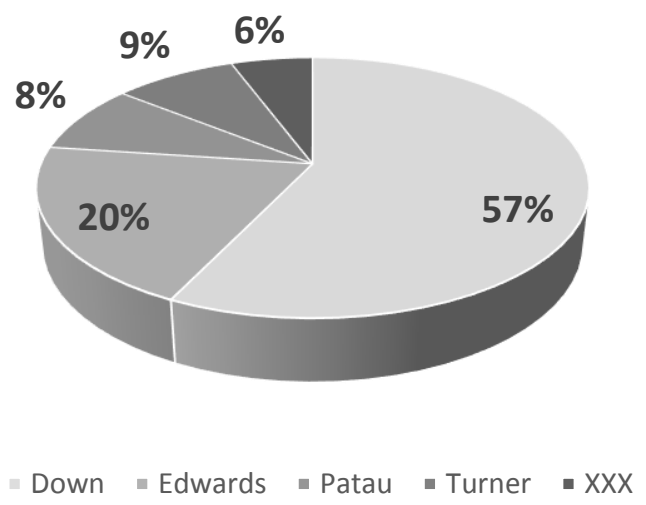

Fig. 6. Distribution of cases with abnormal karyotype in the FMF group with high risk 
Of the 45 cases with high risk of invasive testing, 10 fetuses (22.22\%) had normal karyotype, so they could be considered false positive for numerical chromosomal abnormalities.

Of the 10 fetuses in the FMF group with high risk and normal karyotype, 4 had major cardiac abnormalities that could have contributed to increased translucency and increased risk, and in fact there is actually a gene abnormality and we have tested only the aneuploids. The remaining 6 cases with normal karyotype evolved without finding any structural abnormalities until birth, and the newborns had a favorable evolution.

Given this situation we can claim that the true false positives are only these 6 cases, representing $12 \%$.

From the above data, the specificity of the combined screening is $99.62 \%, 95 \%$ CI $(99.3-99.82 \%)$, the sensitivity being $97.22 \%$, 95\% CI (85.47-99.93\%), with a negative predictive value of 99.96\%, $95 \%$ CI (99.74-99.99\%) and an accuracy of $99.58 \%, 95 \%$ CI (99.26-99.79\%).

Analyzing the situation in which structural anomalies were detected, the indication was from the beginning invasive testing, some cases overlapping with the increased risk indication for aneuploids.

Table 3

TYPES OF STRUCTURAL ANOMALIES IN THE FMF GROUP

\begin{tabular}{|c|c|}
\hline Anomalia structurală & Nr. cazuri \\
\hline Omphalocele & 3 \\
\hline Holoproencecephaly & 1 \\
\hline Diaphragmatic hernia & 1 \\
\hline Major cardiac abnormalities & 20 \\
\hline Absent venous duct & 5 \\
\hline Cystic hygroma & 9 \\
\hline Plurimalformation syndrome & 1 \\
\hline Isolated polydactyly & 1 \\
\hline Dilated rectum - anal imperforation & 1 \\
\hline Left atrial isomerism & 1 \\
\hline Anencephaly & 3 \\
\hline TOTAL & 46 \\
\hline
\end{tabular}

From Table 3 it is observed that the major cardiac anomalies are the most common 20/46 (43.47\%), because they can appear in isolation, microdeletions or within chromosomal syndromes, so of the 20 faces, 6 were with trisomy 21, 3 cases with trisomy 13 and 5 with trisomy 18 . Six cases with major cardiac abnormalities had normal karyotype. Pregnancies with anencephaly faces have not been genetically tested because anencephaly is polygenic, multifactorial and has no indication of genetic testing. (Table 4)

Table 4

ASSOCIATION OF STRUCTURAL ANOMALY / KARYOTYPE IN THE FMF GROUP

\begin{tabular}{|c|c|c|c|c|c|c|}
\hline Structural anomaly & Down & Edwards & Patau & Turner & $\begin{array}{c}\text { Normal } \\
\text { karyotype }\end{array}$ & $\begin{array}{c}\begin{array}{c}\text { Other } \\
\text { anomalies }\end{array}\end{array}$ \\
\hline Omphalocele & 1 & - & - & - & 2 & - \\
\hline Holoproencecephaly & 1 & - & - & - & - & - \\
\hline Hernie diafragmatică & & & & & 1 & \\
\hline Major cardiac abnormalities & 6 & 6 & 3 & - & 6 & - \\
\hline Absent venous duct & - & - & - & - & 5 & - \\
\hline Cystic hygroma & 2 & - & - & 3 & 2 & $\mathrm{XXX}$ \\
\hline Plurimalformation syndrome & - & - & - & - & - & $69 \mathrm{XXX}$ \\
\hline Isolated polydactyly & - & - & - & - & 1 & $\begin{array}{l}\text { S. McKusic } \\
\text { Kaufmann }\end{array}$ \\
\hline $\begin{array}{l}\text { Dilated rectum - anal } \\
\text { imperforation }\end{array}$ & - & - & - & - & 1 & - \\
\hline Left atrial isomerism & - & - & - & - & 1 & - \\
\hline Anencefalie & - & - & - & - & - & - \\
\hline
\end{tabular}

In the TPNI group of 350 cases, we had 4 cases with high risk, 4 invasive tests were performed, of which 3 were confirmed, one case being normal karyotype.

In the FMF group of 2650 cases, we had 69 cases with intermediate risk, they performed TPNI, one being at high risk, where invasive genetic testing was performed and confirmed. The high risk cases were 45,45 invasive tests were performed, of which 35 were confirmed, and 10 had normal karyotype.

A total of 50 invasive genetic tests were performed for the increased risk of aneuploidy, excluding the tests performed for structural abnormalities detected ultrasound without increased risk. Of these, 11 had normal karyotype, and 36 were confirmed (Fig. 7). 


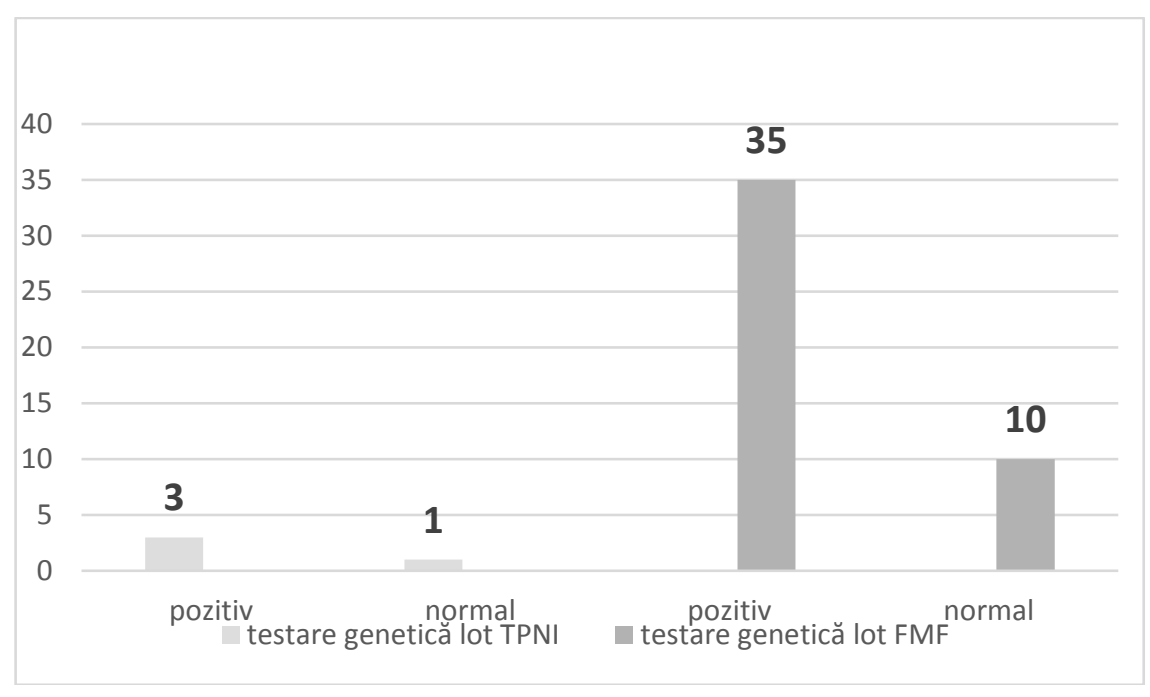

Fig. 7. Invasive testing in the 2 batches

Within the PNIT batch, at the time of the ultrasound and the risk assessment of aneuploids according to the FMF algorithm, we obtained the following results: out of the total 350 cases 5 were at increased adjusted risk, one of the group not interpretable at PNIT, confirmed as being Edwards syndrome and the 3 who were at high risk also at PNT, being genetically confirmed, one was not genetically confirmed, the karyotype being normal. In addition, 5 cases were identified that were at intermediate risk. (Table 5)

Table 5

CASES FROM THE PNIT GROUP EVALUATED FMF

\begin{tabular}{|c|c|c|c|}
\hline & Lot PNIT & Genetically confirmed & Genetically unconfirmed \\
\hline Increased adjusted risk & 5 & 4 & 1 \\
\hline Adjusted intermediate risk & 5 & - & - \\
\hline
\end{tabular}

From the previous data it follows that following the management according to the FMF algorithm we performed 5 genetic tests in the FMF group, of which 4 were confirmed, one being with normal karyotype.

Table 6.

THE RESULT OF THE INVASIVE TESTS ACCORDING TO THE TYPE OF SCREENING

\begin{tabular}{|c|c|c|}
\hline Type of screening & \multicolumn{1}{|c|}{$\begin{array}{c}\text { Invasive testing } \\
\text { number of cases (\%) }\end{array}$} & $\begin{array}{c}\text { False positives } \\
\text { number of cases (\%) }\end{array}$ \\
\hline FMF & $55(1.83 \%)$ & $12(21.81 \%)$ \\
\hline TPNI & $41(1.36 \%)$ & $1(2.43 \%)$ \\
\hline
\end{tabular}

Using Fisher's exact test for comparing invasive test cases, we observed a smaller number of tests (41 vs 55) by using TPNI as a screening method with a statistically significantly lower false positive rate ( $1 \mathrm{vs} 12, \mathrm{p}=0.0153)$. [21-27]

Although the sensitivity, specificity and accuracy of the two screening methods are almost similar, using TPNI screening we obtain a rate of approximately $20 \%$ lower false-positive results, and we also perform a smaller number of invasive tests. [24-29]

\section{Conclusions}

Screening using the non-invasive prenatal test for the detection of aneuploids has a specificity of $99.71 \%, 95 \% \mathrm{CI}$ (98.39-99.99\%), a sensitivity of 100\% 95\% CI (29.24-100\%), with a negative predictive value (NPV) of $100 \%$ and positive predictive value (PPV) of 75\%, 95\% CI (29.76-95.50\%).

The combined screening according to the Fetal Medicine Foundation algorithm shows a specificity of $99.62 \%, 95 \%$ CI (99.3-99.82\%), sensitivity being $97.22 \%, 95 \%$ CI (85.47-99.93\%), with a value negative predictive of $99.96 \%, 95 \%$ CI (99.74-99.99\%) and accuracy of 99.58\%, 95\% CI (99.26-99.79\%).

The sensitivity, specificity and accuracy of the two screening methods are almost similar, using PNIT screening we obtain a rate of approximately $20 \%$ lower false-positive results and we also do a smaller number of invasive tests.

The non-invasive prenatal test is reliable and can be used as a single test for screening for aneuploidies with a very high detection rate and a very low false-positive rate, so it could reduce the number of undiagnosed pregnancies and the number invasive procedures. 
Although TPNI has a low rate of false positive results, it exists and therefore cannot yet be used as a diagnostic test, so a positive TPNI is required to be followed by an invasive test if parents wish to interrupt the task.

Screening by TPNI should not replace first trimester ultrasound in order not to deprive patients of the benefits of early detection of other abnormalities and of preeclampsia prevention.

\section{References}

1. LO YM, LAU TK, ZHANG J, LEUNG TN, CHANG AM, HJELM NM, ET AL. Increased fetal DNA concentrations in the plasma of pregnant women carrying fetuses with trisomy 21. Clin Chem 1999; 45:1747-51.

2. TONG YK, DING C, CHIU RW, GEROVASSILI A, CHIM SS, LEUNG TY, ET AL. Noninvasive prenatal detection of fetal trisomy 18 by epigenetic allelic ratio analysis in maternal plasma: theoretical and empirical considerations. Clin Chem 2006; 52:2194-202.

3. LO YM, TSUI NB, CHIU RW, LAU TK, LEUNG TN, HEUNG MM, ET AL. Plasma placental RNA allelic ratio permits noninvasive prenatal chromosomal aneuploidy detection. Nat Med 2007;13:218-23.

4. DHALLAN R, GUO X, EMCHE S, DAMEWOOD M, BAYLISS P, CRONIN M, et al. A non-invasive test for prenatal diagnosis based on fetal DNA present in maternal blood: a preliminary study. Lancet 2007;369:474-81

5. LO YM, LUN FM, CHAN KC, TSUI NB, CHONG KC, LAU TK, et al. Digital PCR for the molecular detection of fetal chromosomal aneuploidy. Proc Natl Acad Sci U S A 2007;104:13116-21.

6. FAN HC, QUAKE SR. Detection of aneuploidy with digital polymerase chain reaction. Anal Chem 2007;79:7576-9.

7. LUN FM, CHIU RW, CHAN KC, LEUNG TY, LAU TK, LO YM. Microfluidics digital PCR reveals a higher than expected fraction of fetal DNA in maternal plasma. Clin Chem 2008; 54:1664-72.

8. CHIU RW, CANTOR CR, LO YM. Non-invasive prenatal diagnosis by single molecule counting technologies. Trends Genet 2009;25:324-31. 9. ASHOOR G, SYNGELAKI A, WAGNER M, BIRDIR C, NICOLAIDES KH. Chromosome-selective sequencing of maternal plasma cell-free DNA for first-trimester detection of trisomy 21 and trisomy 18. Am J Obstet Gynecol 2012;206:322.e1-5.

10. SPARKS AB, WANG ET, STRUBLE CA, BARRETT W, STOKOWSKI R, MCBRIDE C, et all. Selective analysis of cell-free DNA in maternal blood for evaluation of fetal trisomy. Prenat Diagn 2012;32:3-9.

11. SPARKS AB, STRUBLE CA, WANG ET, SONG K, OLIPHANT A. Noninvasive prenatal detection and selective analysis of cell-free DNA obtained from maternal blood: evaluation for trisomy 21 and trisomy 18. Am J Obstet Gynecol 2012;206:319.e1-9

12. CHIU RW, CHAN KC, GAO Y, LAU VY, ZHENG W, LEUNG TY, et al. Noninvasive prenatal diagnosis of fetal chromosomal aneuploidy by massively parallel genomic sequencing of DNA in maternal plasma. Proc Natl Acad Sci U S A 2008;105:20458-63.

13. FAN HC, BLUMENFELD YJ, CHITKARA U, HUDGINS L, QUAKE SR. Noninvasive diagnosis of fetal aneuploidy by shotgun sequencing DNA from maternal blood. Proc Natl Acad Sci U S A 2008;105:16266-7

14. NHS Fetal Anomaly Screening Programme. Annual Report. NHS Fetal Anomaly Screening Programme. April 2010 - March 2011. London: UK National Screening Committee Programmes Directorate; 2011.

15. WARD P, SOOTHILL P. Fetal anomaly ultrasound scanning: the development of a national programme for England. The Obstetrician \& Gynaecologist 2011;13:211-7

16. CRISTINA TUDORAN, MARIANA TUDORAN, FLORINA PARV, GHEORGHE NICUSOR POP, AHMED ABU-AWWAD, MIHAELA VLAD, MELANIA BALAS, Factors influencing the evolution of pulmonary hypertension in patients with hyperthyroidism, Rev. Chim. (Bucharest), 70, no. 4, 2019, 1328-1332.

17. MARIANA TUDORAN, CRISTINA TUDORAN, MIHAELA VLAD, MELANIA BALAS, AHMED ABU-AWWAD, GHEORGHE NICUSOR POP, Impact of Therapy with L-Thyroxine on the Evolution of Arterial and Aortic Stiffness in Female Patients with Overt and Subclinical Hypothyroidism Rrv.Chim.(Bucharest), 70, no.4, 2019, 1372 - 1376.

18. NICOLAIDES KYPROS H. The 11-13+6 weeks scan, Fetal Medicine Foudation, London, 2004.

19. American College of Obstetricians and Gynecologists Committee on Genetics, Society for Maternal-Fetal Medicine Publications Committee. Committee Opinion No. 545: Noninvasive prenatal testing for fetal aneuploidy. Obstet Gynecol 2012;120:1532-4.

20. FLORICA MEKERES, CAMELIA BUHAS - Spontaneous human combustion, homicide, suicide or household accident - Romanian Journal of Legal Medicine, vol. XXIV, Issue 1, march 2016, ISSN 1221 - 8618

21. LANGLOIS S, BROCK JA, WILSON RD, AUDIBERT F, CARROLL J, CARTIER L, et al. Society of Obstetricians and Gynaecologists of Canada Committee Opinion No. 287. Current status in non-invasive prenatal detection of Down syndrome, trisomy 18, and trisomy 13 using cellfree DNA in maternal plasma. J Obstet Gynaecol Can 2013;35:177-81

22. MEKEREȘ, F., VOIȚĂ, G. F., MEKEREȘ, G. M., \& BODOG, F. D. (2017). Psychosocial impact of scars in evaluation of aesthetic prejudice. Rom J Leg Med, 25, 435-438.

23. MEKEREŞ, F., BUHAŞ, C., RAHOTĂ, D., MOGA, I., VOIȚĂ, F., \& MEKEREŞ, G. M. (2017). A NEW APPROACH TO EXPLORING HUMAN ANATOMY. Romanian Journal of Functional \& Clinical, Macro-\& Microscopical Anatomy \& of Anthropology/Revista Româna de Anatomie Functionala si Clinica, Macro si Microscopica si de Antropologie, 16(3).

24.ILINCA UNTU, ALEXANDRA BOLOȘ, CAMELIA LIANA BUHAȘ, DANIA ANDREEA RADU, ROXANA CHIRIȚĂ, ANDREEA SILVANA SZALONTAY - Considerations on the Role of Palliative Care in the Mourning Period - Revista de cercetare şi intervenție socială. Vol 58, septembrie 2017.

25.ABU AWWAD AHMED, PREJBEANU R., VERMESAN D., DELEANU B., IONITESCU M.., FLORESCU S., VLAD C.D., DUMITRASCU V., Dose Effect Of Local Betamethasone Injection In Low Back Pain, Rev.Chim.(Bucharest), 69, no. 9, 2018, p. 2382 - 2384.

26. SANTORUM M, WRIGHT D, SYNGELAKI A. et al. Accuracy of first-trimester combined test in screening for trisomies 21,18 and 13. Ultrasound Obstet Gynecol 2017; 49: 714-720.

27. ABU AWWAD AHMED, PREJBEANU R., VERMESAN D., BRANEA I., DELEANU B., FLORESCU S., VLAD V. D., Blood Loss Of Pedicle Subtraction Osteotomy For Sagittal Imbalance Spinal Deformity, Rev.Chim.(Bucharest), 69, no. 12, 2018, p. 3680 - 3682.

28. TAYLOR-PHILLIPS S, FREEMAN K, GEPPERT J, et al Accuracy of non-invasive prenatal testing using cell-free DNA for detection of Down, Edwards and Patau syndromes: a systematic review and meta-analysis BMJ Open 2016;6:e010002

29. ABU-AWWAD A, FOLESCU R, POP DL, MOTOC AGM, OPREA DM, TUDORAN M, ZAMFIR CL, FAUR CI, VERMESAN D, DELEANU BN, ANDOR BC, HARAGUS HG. Morphometric characteristics of fibrocartilaginous tissue in the herniated intervertebral disc. Rom J Morphol Embryol, 2019, 60(2):629-634

$\overline{\text { Manuscript received: } 11.11 .2019}$ 
